\title{
Omega Yağ Asitleri: Biyolojik Etkileri ve Bitkisel Kaynakları
}

\section{Omega Fatty Acids: Biological Effects and Herbal Sources}

\section{Bilge Salar ${ }^{1}$}

Orcid: 0000-0003-3373-4759,

Ayşe Kuruüzüm-Uz ${ }^{1}$,

Orcid: 0000-0002-4984-1690,

${ }^{1}$ Hacettepe Üniversitesi Eczac1lik Fakültesi, Farmakognozi AbD., 06100 Ankara, Türkiye

\section{Corresponding author:}

Ayşe Kuruüzüm-Uz

Hacettepe Üniversitesi Eczacılık Fakültesi,

Farmakognozi ABD.,

06100 Ankara, Türkiye

Tel: 03123051089

E-mail: ayseuz@hacettepe.edu.tr

\begin{abstract}
ÖZET
Diyetin önemli bileşenlerinden olan omega yağ asitleri yaygın olarak omega-3, omega-6, omega-9 olarak bilinmektedir. Omega yağ asitlerinin en zengin besin kaynakları bitkisel yağlar ve balık yağlarıdır. Omega-3 ve omega-6 zorunlu olarak dışarıdan alınması gereken esansiyel yağ asitlerindendir. Omega-3, $\alpha$-linolenik asit (ALA) bitkisel kaynaklı iken; eikosapentaenoik asit (EPA) ve dokosaheksaenoik asit (DHA) balıklarda bol miktarda bulunmaktadır. Bitkilerin tohumları ve özellikle findık, ceviz gibi sert kabuklu meyveler başlıca omega yağ asidi kaynaklarıdır.

Başta omega-3 olmak üzere omega yağ asitlerinin kardiyovasküler hastalıklar, bilişsel fonksiyonlar, metabolik bozukluklar, enflamatuvar hastalıklar, oksidatif stres, cilt rahatsızlıkları, göz hastalıkları, psikiyatrik bozukluklar ve Alzheimer gibi birçok hastalıkta olumlu etkileri vardır ve tedavide kullanılmaktadırlar. Ayrıca fetal gelişimin sağlanmasında da etkin rol oynadıkları bilinmektedir. Sağlık üzerindeki yararlı etkilerin görülebilmesi için omega-6/omega-3 oranının düşük olması gerekmektedir. Biyolojik etkilerinin birçoğunun mekanizması henüz tam olarak aydınlatılamamıştır. Bu makalede, önemli omega yağ asitleri hakkında genel bilgilerin, bulundukları bitkisel kaynakların, biyolojik etkilerinin ve kullanımlarının derlenmesi amaçlanmıştır
\end{abstract}

Anahtar Kelimeler: Omega yağ asitleri, Omega-3, Omega-6, biyolojik etki, bitkisel PUFA kaynakları

\footnotetext{
ABSTRACT

Omega fatty acids, one of the important components of the diet, are commonly known as omega-3, omega-6, and omega-9. The richest food sources of omega fatty acids are vegetable oils and fish oils. Omega- 3 and omega- 6 are essential fatty acids that must be taken externally. While mainly omega-3, $\alpha$-linolenic acid (ALA) is of vegetable origin; eicosapentaenoic acid (EPA) and docosahexaenoic acid (DHA) are abundant in fish. Seeds of plants and especially nuts such as hazelnuts and walnuts are the main sources of omega fatty acids.

Omega fatty acids, especially omega-3, have positive effects in many diseases such as cardiovascular diseases, cognitive functions, metabolic disorders, inflammatory diseases, oxidative stress, skin disorders, eye diseases, psychiatric disorders and Alzheimer's and are used in treatment. It is also known that they play an
} 
important role in fetal development. The omega- 6 / omega- 3 ratio should be low in order to see beneficial effects on health. The mechanisms of action have not yet been completely understood. In this article, it is aimed to review general information about important omega fatty acids, plant sources where they are found, their biological effects and uses.

Keywords: Omega fatty acids, Omega-3, Omega-6, biological effect, herbal PUFA sources

\section{Giriş}

Diyette doymamış yağ asidi tüketimi, özellikle uzun zincirli çoklu doymamış yağ asitlerinin kan kolesterolünün azaltılmasının yanı sıra hücre fizyolojisinin düzenlenmesindeki önemi de göz önüne alındığında büyük önem taşımaktadır [1,2]. Memeliler endojen olarak bazı yağları ve yağ asitlerini sentezler. İnsan metabolizması için esansiyel olmasına rağmen, linoleik ve $\alpha$-linolenik asitler gibi doymamış yağ asitleri insan vücudu tarafindan üretilemez. Omega yağ asitleri, doymamış yağ asitleri içerisinde yer alır [3]. Uzun zincirli çoklu doymamış yağ asitleri (LCPUFAs) 18 veya daha fazla karbon atomu içerir ve en az iki çift bağa sahiptir. omega-3 ve omega-6 yağ asitleri olarak iki ana sınıftan oluşurlar. Omega yağ asitleri içeren doğal kaynaklar: tek hücreli canlılar, deniz canlıları, mantarlar ve bitkilerdir $[4,5]$. Bitkisel yağlar ve özellikle ceviz, findık gibi tohum yağları en önemli kaynaklardandır [6].

Omega-3 yağ asitlerinin prekürsörü olan $\alpha$-linolenik asit (ALA) ve omega-6 yağ asitlerinin prekürsörü olan linoleik asit (LA) metabolizasyonları aynı karaciğer enzimleriyle gerçekleşir. ALA, bitkilerde oleik asitten $\Delta 12$ ve $\Delta 15$ desaturaz enzimlerinin etkisiyle oluşmaktadır. Hayvanlarda omega-3, yă asitlerinin üretilmesinde öncül metabolittir ve insanlar için esansiyel yağ asididir. ALA metabolizasyonu sonu- cu eikosapentaenoik asit (EPA) ve dokosaheksaenoik asit (DHA) oluşurken LA metabolizasyonu ile $\gamma$-linolenik asit ve dihomo- $\gamma$-linolenik asit aracılı̆̆ıyla araşidonik asit oluşur ve enflamatuvar yanıt oluşturacak moleküller meydana gelir [7]. Bu durumda diyetle alınan omega 6/omega 3 oranının önemi ortaya çıkmaktadır ve tavsiye edilen, bu oranın 4:1'den az olmasıdır [8]. ALA'nın vücutta EPA'ya dönüşüm oran1 \%8 iken, DHA'ya dönüşüm oranı ise \%1'dir. Dolayısıyla bu yağ asitlerinin dışarıdan alınması gereklidir. Normal şartlarda alınması önerilen ALA miktarı günlük $1 \mathrm{~g}$, DHA ve EPA miktarı ise ayrı ayrı 250 mg'dır [9]. ALA, bitkisel kaynaklı omega-3 iken, EPA ve DHA deniz canlılarında yüksek miktarda bulunan omega-3 yağ asitlerindendir. Tablo 1'de görüldüğü gibi, dışarıdan alınması gereken omega-3 miktarı yaş, cinsiyete göre değişkenlik göstermektedir. Bununla beraber günlük olarak alınması gereken omega-3 miktarının, 14-50 yaş arası kadınlarda hamilelik durumunda $1.4 \mathrm{~g}$ ve emziren kadınlarda ise 1.3 g olduğu belirtilmiştir [10].

1970’li yıllarda çoğunlukla su ürünleri ile beslenen Gröndland Eskimoları'nda, koroner kalp hastal1$\breve{g}$, romatizmal hastalıklar ve kanser vb. görülme sıklığının çok düşük olmasının rapor edilmesiyle birlikte, diyette yer alan su ürünlerinde EPA bulunduğu saptanmıştır. Diyetle alınan EPA'nın antitrombotik ve serum kolesterolünü düşürücü etkilerinden

Tablo 1. Günlük omega-3 alım dozları (g)

\begin{tabular}{cccc}
\hline Yaş & Erkek & Kadın & 0.5 \\
\hline $0-1^{*}$ & 0.5 & 0.7 & 0.9 \\
$1-3^{* *}$ & 0.7 & 0.9 & 1.0 \\
$4-8^{* *}$ & 1.2 & 1.1 \\
$9-13^{* *}$ & 1.6 & 1.1 \\
$14-50^{* *}$ & 1.6 & \\
$51+{ }^{* *}$ & &
\end{tabular}

\footnotetext{
*Total omega-3 grubu

**ALA ( $\alpha$-linolenik asit) grubu
} 
dolayı kardiyovasküler hastalıkları önlediği düşünülmüş ve bu sebeple günümüzde omega yağ asitleri birçok çalışmaya konu olmuştur [11].

EPA ve DHA balık yağlarında yüksek oranda bulunan, birçok hastalığın önlenmesinde veya tedavi edilmesinde önemli etkileri olan omega-3 yağ asitleridir. Yapılan çalışmaların çoğunda enflamasyon ve kardiyovasküler sistem üzerindeki etkileri üzerinde durulmuştur. Omega yağ asitleri başlıca antioksidan, antienflamatuvar, kardiyoprotektif, antikanser etkiye sahiptir. omega-3 ve omega-6 çoklu doymamış yağ asitleri (PUFA), vücutta merkezi sinir sisteminin bileşeni olma ve membran geliştirme gibi önemli roller oynadıklarından ve trombosit agregasyonunda, zara bağlı enzimlerin taşınmasında rol oynadıklarından, gelişim sırasında ve bağışıklık sisteminin işleyişi için insanlar açısından önemlidir. Bunların yanı sıra tip 2 diyabet riski, göz rahatsızlıkları, zihinsel gelişim, demans ve bazı sinir sistemi problemleri üzerinde etkili oldukları da çeşitli araştırmalarla gösterilmiştir $[4,5]$.

Günümüzde, omega-3 kaynağı olarak kullanılan balıkların, civa ve çeşitli çevre kirlilikleri taşımalarından dolayı özellikle çocuklar, hamile ve emziren kadınlar için risk taşımaları, dünya balık stoklarının giderek azalması, vejeteryan tüketimin artması, balık yağlarında istenmeyen kokunun bulunması, kolay okside olabilmeleri gibi nedenlerle, balık ve balık yağı tüketimi azalmaktadır. Bununla beraber pek çok insan diğer yağ kaynaklarının kombinasyonuyla elde edilmiş omega-3 yağ asitleri bakımından zengin diğer kaynaklara eğilim göstermektedir. Bu kombinasyonlar genellikle; sebze, bitkisel tohumlardan elde edilen yağlar ile hayvansal kökenli yağlardan oluşmaktadır [12]. Bu nedenlerle, alternatif PUFA kaynakları üzerine yoğun araştırmalar devam etmektedir.

$\mathrm{Bu}$ makalede, başlıca önemli omega yağ asitleri hakkında genel bilgilerin, bulundukları bitkisel kaynakların ve biyolojik etkilerinin/kullanılışlarının yer aldığı bilimsel araştırmaların derlenmesi amaçlanmıştır.

\section{Kimyasal Yapı ve Genel Bilgiler}

Yağ asitleri içerdikleri bağın tek veya çift oluşuna göre doymuş ve doymamış yağ asitleri olmak üzere iki gruba ayrılırlar (Şekil 1). Doymuş yağ asitlerinin kimyasal yapıları $\mathrm{C}_{n} \mathrm{H}_{2 n} \mathrm{O}_{2}$ dir, doymamış yağ asitleri molekül dizilişlerinde karbon atomları arasında farklı sayıda çifte bağ içermektedirler. Yağ asitlerinin adlandırılmasında karboksil grubundan sonraki ilk karbon atomu $\alpha$, ikinci karbon atomu ise $\beta$ olarak gösterilirken sondaki metil grubu da omega ( $\omega$ veya n) olarak ifade edilir ve metil grubuna en yakın çifte bağ $\omega$ ya da $n$ çifte bağ olarak gösterilir $[13,14]$. Uzun zincirli doymamış yağ asitlerinde ilk çifte

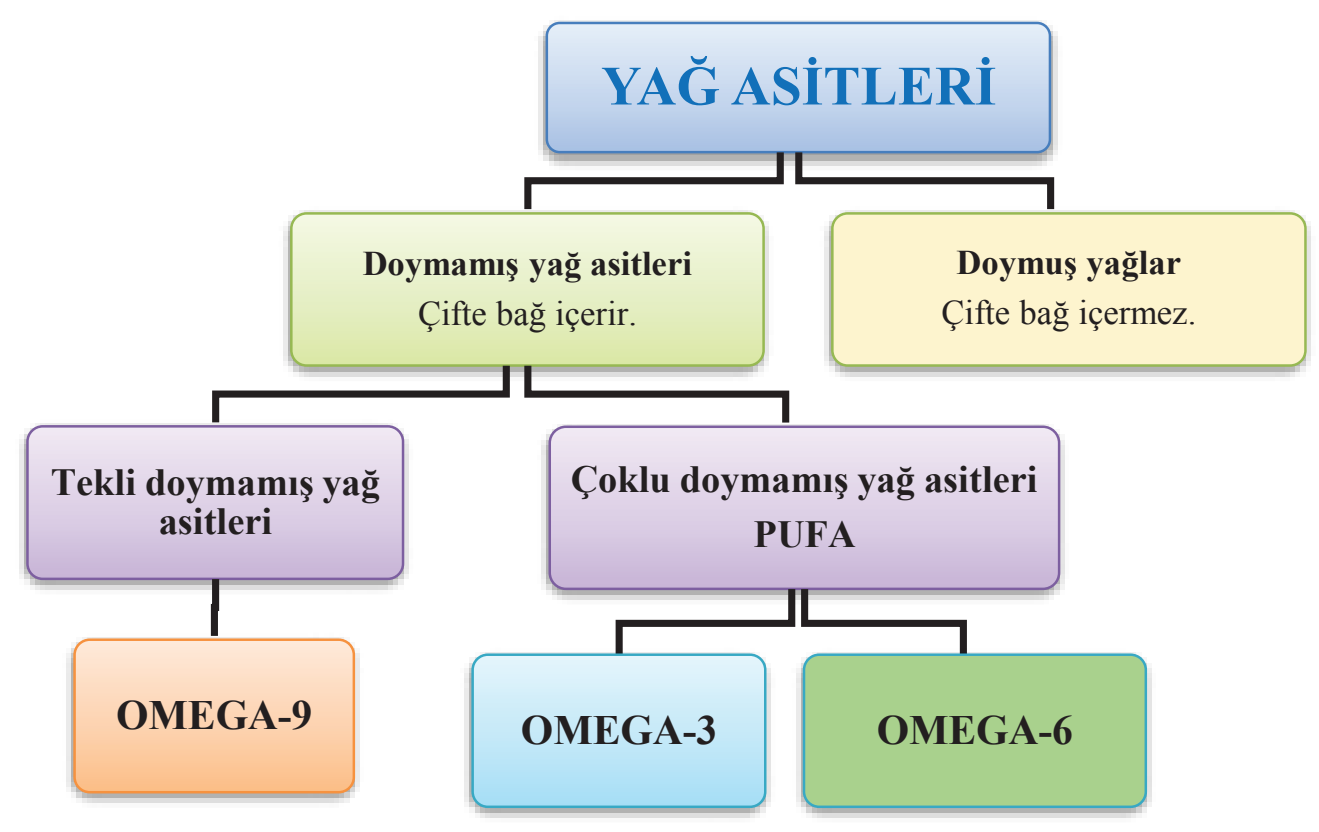

Şekil 1. Omega yağ asitlerinin sınıflandırılması 
bağ, metil grubuna en yakın kaçıncı karbondaysa ona göre $\omega-3, \omega-6$ veya $\omega-9$ şeklinde adlandırılırlar (Tablo 2) $[3,13]$. Yağ asitlerinde çifte bağlar " $\Delta$ " ile gösterilirken x çifte bağın kaçıncı karbonda olduğunu belirtir ve "a:b" şeklindeki ifadede "a" karbon sayısını, "b" çifte bağ sayısını ifade eder [11]. Başlıca önemli omega- 3 yağ asitleri arasında ALA (18:3n3), EPA (20:5n-3), DHA (22:6n-3) ve stearidonik asit (SDA, 18:4n-3) bulunmaktadır.

Temel omega-3 kaynaklarından $\alpha$-linolenik asit (ALA), vücutta EPA ve DHA'ya dönüşse de bu yeterli değildir [10]. Linoleik asit (LA, $\omega-6)$ metabolitleri ise kan basıncını, bağışıklık ve enfeksiyona bağlı enflamasyon tepkilerini denetleyen prostaglandinlerin oluşumunu sağlayan dihomo-gama-linoleik asit ve araşidonik asittir [3,15]. Düşük omega-6/ omega-3 oranının, yüksek prevalansa sahip kronik hastalık riskini azalttığı gösterilmiştir [16]. Dolayısıyla önerilen tüketim oran1 4/1' den az olmasına rağmen batı toplumlarının diyetlerinde omega-6'nın ağırlıkta olduğu oranlarla (10:1, 20:1 gibi) karşılaşılmaktadır $[8,16]$.

Omega-3 yağ asitleri, özellikle balık yağı ve krill yağı preparatları şeklinde piyasada yer almaktadırlar.
Balık yağlarının üretiminde IFOS (The International Fish Oil Standarts) ve GOED (The Global Organization for EPA\&DHA omega-3s) adı verilen Uluslararası Balık Yağı Standartlarına uygunluk onayının olması önemli bir kriterdir. Haftada 3 kez (200-300 g) besin gereksinimini sağlayacak; ringa, uskumru, sardalya ve somon gibi yağ asidi içeriği zengin balıkların tüketilmesi tavsiye edilmektedir.

Omega-6 yă̆ asitlerinden dünyada en çok gama linoleik asit formunda olan "evening primrose oil (Oenothera biennis L. (ezan çiçeği, eşek otu) tohum yağı)" pazarlanmaktadır [17].

Omega-3,-6 ve -9'a kıyasla daha az bilinen omega-5 ve omega-7 yağ asitleri de tıbbi etkileri açısından önemlidir [18,19]. Omega-5 yağ asitlerinin öncüsü olan punisik asit (PA) için en önemli kaynak Punica granatum L. (nar) çekirdeğinin yağıdır [18]. Ayrıca bazı Momordica sp. ve Trichosanthes sp. türlerinde de punisik asit bulunmuştur. Punisik asitin antioksidan, antienflamatuvar, antidiyabetik, lipit düşürücü ve antikanser etkili olduğu çeşitli çalışmalarla desteklenmiştir [19,20]. Palmitoleik asit (PAL), omega-7 yağ asitlerinin kaynağıdır ve Macadamia integrifolia Maiden \& Betche tohum yağında olduk-

Tablo 2. Omega yağ asitleri ve kimyasal yapıları [13]

\begin{tabular}{|c|c|c|c|c|}
\hline $\begin{array}{l}\text { Yağ Asitleri, } \\
\omega \text {-Karakteri }\end{array}$ & $\begin{array}{l}\text { Metil } \\
\text { ucu }\end{array}$ & $\begin{array}{c}\text { Karboksil } \\
\text { ucu }\end{array}$ & Doymuşluk & $\Delta$-Karakteri \\
\hline $\begin{array}{l}\text { Oleik asit (OA) } \\
18: 1, \omega-9\end{array}$ & & & Tekli Doymamış & $18: 1 \Delta^{9}$ \\
\hline $\begin{array}{l}\text { Palmitoleik asit (PAL) } \\
\text { 16:1, } \omega-7\end{array}$ & & & Tekli Doymamış & $16: 1 \Delta^{9}$ \\
\hline $\begin{array}{l}\text { Linoleik asit (LA) } \\
\text { 18:2, } \omega-6\end{array}$ & & & Çoklu Doymamış & $18: 2 \Delta^{9,12}$ \\
\hline $\begin{array}{l}\text { Punisik asit (PA) } \\
\text { 18:3, } \omega-5\end{array}$ & & & Çoklu Doymamış & $18: 3 \Delta^{9,11,13}$ \\
\hline $\begin{array}{c}\alpha \text {-linolenik asit (ALA) } \\
18: 3, \omega-3\end{array}$ & & & Doymamış & $18: 3 \Delta^{9,12,15}$ \\
\hline $\begin{array}{l}\text { Eikosapentaenoik asit (EPA) } \\
20: 5, \omega-3\end{array}$ & & & Çoklu Doymamış & $20: 5 \Delta^{5,8,11,14,17}$ \\
\hline $\begin{array}{c}\text { Dokosaheksaenoik asit } \\
\text { (DHA) } \\
22: 6, \omega-3\end{array}$ & & & Çoklu Doymamış & $20: 6 \Delta^{4,7,10,13,16,19}$ \\
\hline
\end{tabular}


ça yüksek oranlarda bulunur [21]. Bu yağ asidinin cildi yenilediği, mukozal membran hidrasyonunu artırdığı, HDL (High Density Lipoprotein) kolesterol seviyesini ve insülin hassasiyetini arttırdığ gösterilmiştir [19]. Omega-9 yağ asitlerinin kaynağ olan oleik asit (OA) için bilinen en önemli kaynak, Olea europaea L. (zeytin) meyvelerinden elde edilen zeytinyağıdır. Oleik asitin vücutta glukoz dengesini sağlayarak, lipid seviyesini düzenleyerek ve enflamasyonu azaltarak kardiyovasküler hastalık riskini azalttığı birçok çalışma ile kanıtlanmıştır [22].

\section{Omega Yağ Asitlerinin Biyolojik Etkileri ve Kullanımları}

Omega yağ asitlerinin, kardiyovasküler sistem hastalıklarının önlenmesi başta olmak üzere beyin gelişimi, bağışıklık sisteminin güçlenmesi, enflamasyonun azaltılması, kan pıhtılaşmasının önlenmesi, kolesterolün düzenlenmesi, diyabet gelişiminin önlenmesi, görme kusurları ve sinirsel bozuklukların engellenmesi ve kanser riskinin azaltılması gibi durumlarda etkili olduğu bilinmektedir.

$\mathrm{Bu}$ yağ asitlerinin eksiklikleri durumunda ise cilt kuruluğu, astım, öğrenme eksikliği, şeker hastalığ ve kanser gelişimi söz konusu olabilir [5,23,24].

Omega yağ asitlerinin alınan dozu arasında denge kurmak çok önemlidir, yüksek seviyede kullanım vücutta yağ birikmesine neden olabilir. Başlıca yan etkiler balık kokusu ve nadiren görülen bulantı, ishal vb mide-barsak problemleridir. Yüksek dozlarda omega-3 alımı kanama riskini arttırabilir ve immün sistem üzerinde yan etkilere neden olabilir. Fakat şimdiye kadar omega-3 takviyesi yapılan kişilerde yüksek doz aldıklarında, hatta başka antikoagülanları kullandıklarında dahi ciddi bir kanama bildirilmemiştir [3]. Omega yă̆ asitlerinin fazla tüketimi ile ayrıca denizlerde civa birikimi nedeniyle fazla balık tüketimine dayanan civa maruziyeti riski dikkat edilmesi gereken ve tartışılan konulardandır $[6,10]$.

Özellikle bitkisel kaynaklarda yer alan omega-3 ve omega-6 yağ asitlerinin başlıca biyolojik aktiviteleri ve kullanılışları aşağıda özetlenmiştir.

\subsection{Antienflamatuvar Etki}

Enflamasyon romatizma, kanser, ülseratif kolit, otoimmün sistem hastalıkları gibi birçok ciddi hastalı- ğın mekanizmasında rol oynamaktadır. Omega yağ asitlerinin enflamasyon ile ilişkisi metabolizasyonları sonucu enflamasyon mediyatörlerini oluşturması ile açıklanabilir. Çünkü omega-3 yağ asitlerinin metaboliti olan eikosapentanoik asit (EPA) ve doksahekzaenoik asit (DHA), resolvinler ve protektinler gibi antienflamatuvar etkili moleküllerin oluşumunda görev alırken, omega-6 yağ asitlerinin metabolizasyonu sonucu oluşan eikosanoitlerden araşidonik asit (AA), prostaglandinler ve lökotrienler gibi proenflamatuvar özellikli moleküllerin oluşumunda rol oynarlar [7,25]. Omega-3 yağ asitleri, omega-6 kaynaklı enflamasyon mediyatörlerinin oluşumunu azaltarak enflamasyon yanıt oluşumunu düzenlerler [26]. Ancak, omega-6/omega-3 oranının yüksek olmas1 enflamasyon oluşumunu tetiklemektedir [27,28].

\subsection{Antioksidan Etki}

Normal metabolizma veya çevresel faktörlerle oluşan serbest radikallerin yol açtığı oksidatif stres; kanser gelişimi, sinir hücresi hasarları, kardiyovasküler rahatsızlıklar gibi hastalıkların sebebi olabilmektedir [29,30].

DHA alımının, glutatyon redüktaz aktivitesini arttırarak ve oksitlenmiş protein birikimini engelleyerek nörolojik sistemi oksidatif strese karşı koruduğu gösterilmiştir [30]. Oksidatif stresin çevresel sebeplerinden biri olan sigara dumanına maruz kalan farelerden omega-3 takviyesi verilenlerde vasküler oksidatif stresin azaldı $\breve{g} 1$ ve nitrik oksit kaynaklı vazodilatasyonun sağlandığı gözlenmiştir [31]. Kronik böbrek hastalığına sahip erkek sıçanlar ile yapılan çalışmada omega-3 alımının atardamarlarda azalmış endotelyal nitrik oksit sentaz ekspresyonunu normale çevirdiği görülmüştür [32].

Gebelik süreci ve emzirme döneminde alınan EPA ve DHA takviyesinin yenidoğan bebeklerde ve annelerde oksidatif stresi azalttığı ve aynı zamanda annelerde antioksidan etkili $\alpha$-tokoferol seviyesini de arttırdığı gözlenmiştir [33].

Yaşa bağlı olarak oksidatif stresin tetiklediği maküler dejenerasyonun DHA alımı arttırılıp omega-6 alımı azaltılmasıyla engellenebileceği epidemiyolojik çalışmalarla gösterilmiştir [34].

DHA, oksidatif stresin aracılık ettiği proenflamatuvar gen indüksiyonunu inhibe eden nöroprotektin isimli mediyatörün de öncüsüdür [35]. Ancak omega-6 kaynaklı AA, yüksek seviyelerde reaktif oksijene 
sebep olarak proenflamatuvar sitokin salımına da neden olmaktadır. Bu durumda omega-6/omega-3 oranının doğru şekilde sağlanması antioksidan etki açısından da önem kazanmaktadır [30].

\subsection{Kardiyovasküler Sistem Üzerine Etkileri}

Günümüzde başta kardiyovasküler sistem hastalıklar1 olmak üzere birçok hastalığın ilerlemesinin önlenmesinde diyetin önemli bir faktör olduğu bilinmektedir [36]. Omega 3 yağ asitlerinin, kardiyovasküler hastalık riski oluşturan birçok mekanizma üzerinden etkili olduğu kayıtlıdır [6;26]. Bu yağ asitleri miyokard enfarktüsü riskini; kan lipid ve trigliserid düzeyini azaltarak ve pıhtılaşma mekanizmasını ve enflamasyon yanıtını düzenleyerek, ateroskleroz riskine karşı koruma sağlar ve kardiyoprotektif etkinliğini ortaya koyar [36,37]. Birçok iyon kanalı aktivitesini düzenleyerek ve enflamatuvar sitokinleri azaltarak ventrikül kapasitesinin gelişmesini destekler, antiaritmik etkinlik gösterir [38].

Yapılan bir klinik çalışmalarda EPA+DHA uygulamasından sonra açlık trigliserit düzeyi ALA uygulamasına kıyasla daha düşük sonuçlar vermiştir, EPA/ DHA takviyesinin miyokard infarktüsü geçirmiş hastalarda ani kardiyak ölümden koruduğu kanıtlanmıştır [39,40]. ALA ve LA kıyaslandığında ise ALA uygulaması sonucu daha yüksek HDL kolesterol seviyelerine ulaşılmıştır [41].

Diyabette ikincil korumanın sağlanması ve hipertansiyon, atrial fibrilasyon, inme gibi durumların önlenmesinde de omega yağ asitlerinin rol oynadığı düşünülmektedir. Omega-3 desteği ile doğrudan glisemik kontrol etkinliği tespit edilememiş olsa da hayvan deneylerinde insülin duyarlılığını arttırarak glisemik kontrolün sağlandığı da gözlenmiştir [42,43]

\subsection{Göz $\ddot{U} z$ erine Etkileri}

Toplumun genelinde gözlenen göz kuruluğu, alerjik konjuktivit ve kontakt lens intoleransı gibi birçok göz rahatsızlığı kronik enflamasyonla ilişkilendirilmiştir [44]. Omega-3 yağ asitlerinden biri olan DHA, retina membranı için yapısal bir bileşendir ve retinal sinyal mekanizmas1, retina hücre ekspresyonu ve farklılaşması üzerinde etkilidir [45,46]. Omega-3 yağ asitleri, enflamasyonu ve lakrimal bezlerin apoptozunu azaltarak gözyaşı üretimini artırmaktadır. Yapılan klinik çalışmalar ve fare deneyleri ile omega-3 yağ asitlerinin kuru göz sendromu insidansını azalttığı 1 ve DHA'ya ek olarak ALA'nın da oküler yüzey için iyi bir antienflamatuvar olduğu gösterilmiştir $[17,44]$. Tip 2 diyabette gelişen oküler yüzey değişimlerini azalttığı da tip 2 diyabetli hastalar üzerinde yapılan çalışmayla saptanmıştır [47].

\subsection{Sinir Sistemi Üzerine Etkileri (Depresyon Tedavisi/Hafıza Gelişimi/Öğrenme)}

Beyin ve sinir dokuları özellikle uzun zincirli çoklu doymamış yağ asitleri bakımından zengin içeriğe sahiptir [4]. Omega-3 yağ asitlerinden biri olan DHA hayvanlarda ve diğer memelilerde beyin ve retinada bulunur ve membran geçirgenliğini, membrana bağlı enzimlerin aktivitesini, iyon geçişlerini, sinyal iletimini düzenlemektedir [48].

Omega yağ asitlerini de kapsayan uzun zincirli çoklu doymamış yağ asitlerinin beyin fonksiyonları üzerindeki etkileri; sinirsel membran akışkanlığı değişikli$\breve{g i}$, membran aktivitesine bağlı enzimlerin değişikliği ve bunların sayısı ile reseptör afinitesi değişimleri, sinirsel membranlardaki iyon kanallarının işlevinin değişmesi, beyin peptitleri ve nörotransmitterlerin üretiminde meydana gelen değişiklikler ile açıklanabilmektedir [49]. Dolayısıyla birçok nöropsikiyatrik hastalık, mental bozukluk, bilişsel bozukluk, demans ve dikkat eksikliği gibi durumların oluşumu ve tedavisinde önemli rol oynamaktadır [48,35]. Psikiyatrik bozukluklarda esansiyel yağ asitlerinin birkaç potansiyel etki mekanizması olduğu çeşitli araştırmalarda gösterilmiştir. Bunlar şu şekilde sıralanabilir: 1) Vagal mekanizma üzerinden kalp hızının düzenlenmesi ve serebral kan akışının değişimi; 2) Gen ekspresyonunun düzenlenmesi; 3) Nöroendokrin sistem üzerindeki değişiklikler (serotonerjik nörotransmisyon artışı, dopaminerjik işlevdeki değişiklikler, kortikotropin salgılayıcı faktör düzenlenmesi); 4) Antienflamatuvar etkinlik (EPA ve AA arasındaki enzimatik aktivite için yarış ve inflamasyon yanıtın azaltılması) ve 5) Sinyal iletiminin düzenlenmesi (Proteinkinaz C inhibisyonu, ikincil mesajcıların baskılanması, artmış sinaps oluşumu, sinirsel apoptozun önlenmesi) $[36,48,50,51]$

Düşük omega-3 seviyesi depresyonun patofizyolojik sebeplerinden biridir [52]. Depresyonlu kişilerde azalmış omega-3/omega-6 oranına da rastlanmaktadır. Omega-3 yağ asitleri, serotonin üretimini hızlandırarak depresyonun şiddetini azaltmaktadır [37]. 
Omega-3 yağ asitleri enflamasyon sitokinlerinin fazla aktivitesini baskılayarak ve bağışıklıkta görevli T hücrelerinin aktivitesini kontrol ederek psikolojik bozuklukların azaltılmasında önemli bir role sahiptir [37,53].

Bir başka nörolojik rahatsızlık olan şizofreni hastalarında, beyin omurilik sıvısında ve dolaşımda proenflamatuvar sitokin konsantrasyonu artmış ve omega-3 yağ asitlerinden EPA ve DHA seviyesi azalmıştır [54]. 20 hasta ile yapılan bir çalışmada yüksek omega-3 alan hastalarda şizofrenik semptomların ve tardif diskinezinin şiddetinin azaldığı gösterilmiştir [53].

Diğer bir çalışmada insan beyin korteksinde ve beyinciğinde DHA seviyesinin 18 yaşına kadar arttığ ve yaşla birlikte AA azalırken ALA miktarının arttığ bulunmuştur [35]. Yaşla birlikte gelişen bir hastalık olan Alzheimer için DHA alımının hastalığa sebep olan beyin plaklarını durdurarak ilerleyişi yavaşlattığı farelerde gösterilmiştir [54]. Yaşla birlikte ALA artışı DHA'ya dönüşerek DHA eksikliğini geri çevirebilir ancak bilişsel fonksiyonlar için DHA'nın da tek basına yeterli olmadığı sonucuna ulaşılmıştır $[35,49]$. Alzheimer hastalarının yaşam kalitesindeki artışın sadece 4:1 omega-3/omega-6 oranında sağlandığı gözlenmiştir [49].

\subsection{Kanser Hücreleri Üzerine Etkileri}

Kanser, dünya çapında en yaygın ölüm nedenleri arasında ikinci sırada yer almaktadır. Omega-3 yağ asitlerinden EPA ve DHA doza ve zamana bağlı olarak kolorektal kanser, prostat kanseri, akciğer kanseri, melanoma ve melanom olmayan cilt kanseri, meme kanseri gibi birçok solid kanserde ve miyeloid lenfoma gibi hematolojik kanserlerde apoptozu uyarabilmektedir. [55,56].

Kemoterapi alan mide kanseri hastaları ve miyeloma hastaları için omega yağ asidi ile desteklenen gruplarda anti-apoptotik olarak tanımlanan BCL2 (B Cell Lymphoma-2) proteini gen ekpresyon h1zının düştügü ve apoptozun uyarıldığ1 görülmüştür $[57,58]$. Omega yağ asitlerinin enflamasyon gideren mediyatörlerin oluşumunda rol oynaması yoluyla da kolorektal kanser üzerinde etkisi bulunmuştur [59].

Erkeklerde kanser ilişkili ölüm nedenlerinin başında gelen prostat kanseri üzerinde yapılan in vitro çalışmalarda düşük konsantrasyonlarda EPA uygulamasının prostat kanseri büyümesini inhibe ettiği gös- terilmiştir [60,61]. Başka bir çalışmada ise omega-6 ve ALA uygulanan farelerde tümör büyüklüklerinin benzer olduğu ancak EPA ve DHA uygulanan farelerde ise tümör boyutunda $\% 30$ azalma olduğu gözlenmiştir [62].

Kadınlarda en yaygın ikinci ölüm nedeni olan meme kanserinde in vitro ve in vivo çalışmalarla omega yağ asitlerinin yine apoptoz, enflamasyon yanıt, tümör büyüklüğü değişiklikleri gibi benzer mekanizmalarla yararlı etkileri gösterilmiştir [25].

Ayrıca, yapılan klinik çalışmalarla omega-3 alımının immün sistem baskılanmasını ve proenflamatuvar yanıtı azaltarak kanserojenik UV radyasyona bağl1 genotoksisiteden cildi koruduğu gösterilmiştir. Melanom olmayan cilt kanseri üzerinde yararlı etkilerinin olabileceği sonucuna varılmıştır [56].

\subsection{Obezite Üzerine Etkileri}

Omega-3 yağ asitleri şekerlerden yağ yapan yağ asidi sentaz enzimini inhibe ederek yağ depolanmasını azaltır. DHA yağ depolanmasını azaltıcı etkisi ALA'dan daha fazladır. DHA insülin direncini azaltarak da zayıflamayı sağlar. Yüksek omega 6/omega 3 oranı, hayvan ve insanlar üzerinde yapılan çalışmalarda kilo almayla ilişkilendirilirken, buna karşılık yüksek omega 3 alımı kilo alma riskini düşürmektedir. Hayvanlarda LA/ALA oranın düşürülmesi obesite ve kilo alımına karşı koruyucudur. Adipoz doku, yağ asitlerinin işlenmesi için ana periferal organdır ve AA adiposit farklılaşması için gereklidir (adipogenez). Yiyeceklerle alınan LA ve AA içeriğinin fazla olmas1, adipoz dokularda AA/EPA+DHA oranını artırmakta, bu da adipogenezi stimüle eden PGI2 ve oksitlenmeyi önleyen PGF2 gibi AA metabolitlerinin üretimini yükseltmektedir. Buna karşılık, EPA ve DHA içeriğinin fazla alınması adipoz dokularda, adipoz doku kaybına neden olarak homeostazı sağlar ve mitokondriyal biyogenezi artırır. Yüksek omega-6 yağ asidi, insülin direncine sebep olurken, omega-3 yağ asitleri homeostazını sağlar ve kilo kaybına neden olur. Omega-6/omega-3 oranın 1-2/1 olmas1, fiziksel aktiviteyle birlikte obeziteyi önlemede önemli bir diyet faktörüdür $[3,27]$.

\subsection{Diğer Kullanımları}

Yağ asitlerinin antienflamatuvar ve trigliserit düşürücü etkileri gibi biyolojik etkilerinden dolayı ilaç 
etken maddesi olarak kullanımları yanında, ilaçlarda lipit formülasyonlarının hazırlanmasında yardımeı bileşenler (eksipiyanlar) olarak yaygın şekilde kullanımları bulunmaktadır. Özellikle yağ emülsiyonlarının ve lipozomların hazırlanmasında taşıyıcı olarak kullanılırlar. Ayrıca, yağ asitleri tek başına veya karışımların bir parçası olarak sabun, yağ emülsiyonları ve lipozomlar halinde kozmetiklerde sıklıkla kullanılmaktadırlar [13].

\section{Omega Yağ Asitleri İçeren Bitkiler}

Mevcut esansiyel yağ asidi kaynaklarına alternatif arayışıyla yapılan çalışmalarda, farklı bitkilerin yă asidi profilleri incelenmekte ve birçok bitki zengin yağ içerikleri ile önem kazanmaktadır (Tablo 3, 4).

\section{Sonuç}

Omega yağ asitleri, kardiyovasküler hastalıklar, yüksek kolesterol, diyabet, göz hastalıkları, kanser, Alzheimer, depresyon gibi birçok hastalık üzerinde olumlu etkilere sahiptir. Bunların yanı sıra antienflamatuvar etkinlik göstermekte ve oksidatif stres üzerindeki yararlı etkileri nedeniyle birçok hastalığın tedavisinde rol almaktadırlar [48].

Omega yağ asitleri arasında, esansiyel olmaları yani vücutta sentezlenmeyip endojen olarak alınmaları gerektiğinden omega-3 ve omega- 6 yağ asitleri daha çok öne çıkmaktadır. Ancak omega-6 metabolitlerinin, proenflamatuvar prostaglandinleri oluşturmaları sebebiyle enflamasyonu tetiklemesi dikkat çeken bir husustur. $\mathrm{Bu}$ nedenlerle çoğu bilimsel araştırmada genel olarak omega-3 yağ asitleri üzerinde çalışmalar yapılmış ve yararlı etkileri tartışılmıştır. Omega-3 yă asitlerinden bitkisel kaynaklı ALA'dan ziyade, deniz canlılarından elde edilen EPA ve DHA ön plandadır. ALA metabolizasyonu sonucu EPA ve DHA oluşmaktadır. İnsan vücudunda LA rezervinin yüksek olması ALA'nın EPA ve DHA'ya dönüşümünün yavaşlamasına neden olmaktadır. $\mathrm{Bu}$ nedenle diyete ALA yönünden zengin besinlerin eklenmesi önemlidir [29].

Bitkilerde yağ asidi kompozisyonunu sıcaklık, enlem derecesi ve lokasyon, ekim zamanı, kuraklık, toprak gibi çevresel faktörlerle beraber genetik ve morfolojik birçok faktör belirlemektedir [81]. Tablo 3.'de yer alan bitkilerden yaygın kullanımı olan ve en yüksek ALA oranına sahip bitkilerden ikisinin Linum usitatissimum L. (keten) (\%61) ve Salvia hispanica L. (çiya) (\%60) olduğu görülmektedir. S. hispanica, Lamiaceae familyasına ait daha çok tohumlarının tüketildiği ve Avrupa'da son yıllarda popüler olan bir bitkidir. Çiya tohumu üzerinde yapılan çalışmalarda çiya tüketimi ile kardiyovasküler hastalıkların, diyabetin, hiperkolesterolün, kan pıhtılaşmasının önlenmesi; epilepsi ve strese karşı koruma sağlaması arasında ilişki olduğu sonucuna varılmıştır. Ayrıca gebelik süresince çiya tüketiminin fetüsün beyin ve retina gelişimine destek sağladığı görülmüsştür. Alzheimer gibi bilişsel bozukluklarda da etkili olduğu bilinmektedir $[82,83]$. 21 gün boyunca günlük $5 \mathrm{~g}$ çiya tohumu verilen test grubu ile kontrol grubunun kıyaslandığı bir çalışmada test grubunun problem çözme yeteneğinin ve sözel zekasının geliştiği gözlenmiştir [82]. Ayrıca çiya tohumlarının aşırı kilolu yetişkinlerde kilo kontrolüne ve aşırı kilonun risk oluşturduğu hastalıkların önlenmesine yardımc1 olduğu, vücutta ALA konsantrasyonunu arttırdığ 1 gösterilmiştir [83]. L. usitatissimum (keten), Linaceae familyasına ait bir tür olup tohumları biyolojik etkileri nedeniyle yaygın olarak kullanılmaktadır. Zengin ALA içeriği ile antitrombotik, antihiperlipidemik, antiinflamatuvar, antikanser, antidiyabetik özellik göstermektedir. Bunun yanı sıra kardiyovasküler hastalıklar ve dikkat eksikliği, Alzheimer gibi bilişsel bozuklukların da önlenmesinde etkili olduğu bilinmektedir $[84,85]$. Her iki bitki de gida desteği olarak değerlendirilebilecek potansiyele sahip sağlik endüstrisi için önemli kaynaklardandır $[83,85]$.

Omega-3 yağ asitlerinin kardiyovasküler sistemi koruduğu, kolesterolü düzenlediği, kanserli hücre gelişimini engellediği, beyin ve retina gelişimini desteklediği, fetal gelişime katkı sağladığı ve psikiyatrik hastalıkların tedavisinde önemli rol oynadığı yönünde birçok kanıt bulunmaktadır. Omega-3 yağ asitlerinin tümör hücrelerinin konvansiyonel tedavisine duyarlılığı arttırdığı ve seçici toksisite sağlayarak normal hücrelerin etkilenmesini engellediği gösterilmiştir [55]. Miyeloma hastaları ve sağlıklı insanlarla yapılan bir çalışma da EPA ve DHA'nın malign hücrelerde seçici toksisite sağladığını ancak sağlıklı insanların hücrelerini koruduğunu kanıtlamaktadır [58]. Ayrıca kemoterapinin azalttığı yaşam kalitesinin yükseltilmesi ile omega-3 ve probiyotik kombine kullanımı arasında ilişki bulunmuştur [59].

Yapılan çalışmalar, ülseratif kolit ve Chorn hastalı$\breve{g}_{1}$ gibi kronik enflamasyonlu bağırsak hastalıklarında, omega-3 yağ asitleri (EPA ve DHA) tüketiminin 
Tablo 3. Dünya genelinde bitkilerden elde edilen yağların başlıca omega yağ asidi içerikleri

\begin{tabular}{|c|c|c|c|c|c|c|}
\hline Bitki & Familya & $\begin{array}{c}\text { Çalış1lan } \\
\text { Kısım }\end{array}$ & $\begin{array}{c}\omega-3 \\
(\mathrm{ALA}) \\
(\%)\end{array}$ & $\begin{array}{c}\omega-6 \\
(\mathrm{LA}) \\
(\%)\end{array}$ & $\begin{array}{c}\omega-9 \\
(\mathrm{OA}) \\
(\%)\end{array}$ & Kaynak No \\
\hline Actinidia chinensis $\mathrm{Pl}$. & Actinidiaceae & Tohum & 62.3 & 16.1 & 12.6 & 63 \\
\hline Celosia argentea $\mathrm{L}$. & Amaranthaceae & Tohum & & 51.5 & 22.3 & 64 \\
\hline Achillea crithmifolia $\mathrm{W}$. et. $\mathrm{K}$. & Asteraceae & Tohum & 7.4 & 41.3 & 15.4 & 65 \\
\hline Achillea lingulata $\mathrm{WK}$. & Asteraceae & Tohum & 25.9 & 24.3 & 6.6 & 65 \\
\hline Achillea nobilis $\mathrm{L}$. & Asteraceae & Tohum & 16.8 & 21.6 & 6.3 & 65 \\
\hline Carthamus tinctorius L. & Asteraceae & Tohum & & 78 & 10 & 66 \\
\hline Helianthus annuus L. & Asteraceae & Tohum & $<1$ & 63 & 22 & 67 \\
\hline Brassica juncea L. & Brassicaceae & Tohum & $18.3-22.8$ & $17.4-22.4$ & $\begin{array}{r}12.5- \\
16.69\end{array}$ & 68 \\
\hline Brassica carinata $\mathrm{L}$. & Brassicaceae & Tohum & 18.2 & 15.1 & 8.42 & 68 \\
\hline Brassica napus L. & Brassicaceae & Tohum & 10 & 22 & 62 & 69 \\
\hline Brassica oleracea L. & Brassicaceae & Tohum & $17.66-20$ & 11.4413 .30 & $\begin{array}{l}14.21- \\
17.81\end{array}$ & 68 \\
\hline Camelina sativa $\mathrm{L}$. & Brassicaceae & Tohum & $35-40$ & $15-20$ & & 70 \\
\hline Sisymbrium irio L. & Brassicaceae & Tohum & & 30.3 & 30.7 & 64 \\
\hline Cannabis sativa $\mathrm{L}$. & Cannabaceae & Tohum & 22 & 56 & 9 & 67 \\
\hline Arachis hypogaea $\mathrm{L}$. & Fabaceae & Tohum & & $36-67$ & $15-43$ & 71 \\
\hline Glycine $\max \mathrm{L}$. & Fabaceae & Tohum & 8 & 55 & 23 & 67 \\
\hline Ribes nigrum $\mathrm{L}$. & Grossulariaceae & Tohum & 13 & 48 & 11 & 67 \\
\hline Perilla frutescens $\mathrm{L}$. & Lamiaceae & Tohum & 66.6 & 15.4 & 0.2 & 72 \\
\hline Salvia hispanica $\mathrm{L}$. & Lamiaceae & Tohum & 60 & 20 & & 73 \\
\hline Linum usitatissimum L. & Linaceae & Tohum & 61 & 15 & 15 & 67 \\
\hline Aesculus indica Colebr. & Meliaceae & Tohum & 23.4 & 47 & & 64 \\
\hline Oenothera biennis L. & Onagraceae & Tohum & & 76 & 8 & 67 \\
\hline Abies pindrow Royle & Pinaceae & Tohum & 1.4 & 6.5 & 76.1 & 64 \\
\hline Zea mays $\mathrm{L}$. & Poaceae & Tohum & 1 & 60 & 25 & 67 \\
\hline Portulaca oleracea $\mathrm{L}$. & Portulacaceae & Yaprak & 50 & 15 & & 74 \\
\hline Rubus occidentalis L. & Rosaceae & Tohum & 35 & $55-58$ & & 75 \\
\hline Ulmus wallichiana Planchon & Ulmaceae & Tohum & & 31.6 & 29 & 64 \\
\hline Vitis vinifera $\mathrm{L}$. & Vitaceae & Tohum & & $66.0-75.3$ & $13.9-23.9$ & 76 \\
\hline
\end{tabular}


Hacettepe University Journal of the Faculty of Pharmacy

Tablo 4. Türkiye'den toplanmış bitkilerden elde edilen yağların omega yağ asidi içerikleri

\begin{tabular}{|c|c|c|c|c|c|c|}
\hline Bitki & Familya & $\begin{array}{l}\text { Çalışılan } \\
\text { Kısım }\end{array}$ & $\begin{array}{c}\omega-3 \\
(\mathbf{A L A}) \\
(\%)\end{array}$ & $\begin{array}{c}\omega-6 \\
(\mathrm{LA}) \\
(\%)\end{array}$ & $\begin{array}{c}\omega-9 \\
(\text { OA) } \\
(\%)\end{array}$ & Kaynak No. \\
\hline Pancratimum maritimum L. & Amaryllidaceae & Tohum & & 46.1 & 32.4 & 77 \\
\hline Eryngium maritimum L. & Apiaceae & Tohum & 0.1 & 30.2 & 56.6 & 77 \\
\hline Cionura erecta $\mathrm{L}$. & Apocynaceae & Tohum & & 43.9 & 23.5 & 77 \\
\hline Helianthus annuus L. & Asteraceae & Tohum & & $90-92$ & & 78 \\
\hline Corylus avellana L. & Betulaceae & Tohum & & $10-12$ & $75-82$ & 78 \\
\hline $\begin{array}{c}\text { Alkanna tinctoria Tausch ssp. } \\
\text { tinctoria }\end{array}$ & Boraginaceae & Tohum & 30.4 & 24.1 & & 79 \\
\hline Anchusa azurea Miller var: azurea & Boraginaceae & Tohum & 0.22 & 39 & & 79 \\
\hline $\begin{array}{c}\text { Anchusa leptophylla Roemer \& } \\
\text { Schultes ssp. leptophylla }\end{array}$ & Boraginaceae & Tohum & 13 & 26.1 & & 79 \\
\hline Anchusa undulata ssp. hybrida Ten. & Boraginaceae & Tohum & 12 & 27.5 & & 79 \\
\hline Borago officinalis L. & Boraginaceae & Tohum & 0.2 & 35.2 & & 79 \\
\hline Cordia myxa L. & Boraginaceae & Tohum & 0.4 & 65.6 & & 79 \\
\hline Cynoglossum creticum Mill. & Boraginaceae & Tohum & 10.6 & 1.4 & & 79 \\
\hline Echium angustifolium Mill. & Boraginaceae & Tohum & 40.4 & 17.1 & & 79 \\
\hline Echium italicum L. & Boraginaceae & Tohum & 43 & 10.6 & & 79 \\
\hline Echium plantagineum L. & Boraginaceae & Tohum & 33.3 & 15.2 & & 79 \\
\hline Echium vulgare L. & Boraginaceae & Tohum & 36.1 & 16.9 & & 79 \\
\hline Heliotropium dolosum L. & Boraginaceae & Tohum & 0.3 & 68.3 & & 79 \\
\hline Heliotropium europaeum L. & Boraginaceae & Tohum & 0.3 & 68.3 & & 79 \\
\hline Lithospermum purpurocaeruleum L. & Boraginaceae & Tohum & 35 & 14.8 & & 79 \\
\hline $\begin{array}{l}\text { Myosotis ramosissima Rochel ex } \\
\text { Schult. }\end{array}$ & Boraginaceae & Tohum & 12.8 & 25.2 & & 79 \\
\hline Myosotis sicula Guss. & Boraginaceae & Tohum & 22.1 & 23.8 & & 79 \\
\hline $\begin{array}{c}\text { Nonea pulla (L.)DC. ssp. monticola } \\
\text { RECH. FIL. }\end{array}$ & Boraginaceae & Tohum & 13.7 & 29.9 & & 79 \\
\hline Onosma bulbotrichum DC. & Boraginaceae & Tohum & 8.7 & 18.5 & & 79 \\
\hline Onosma sericeum Willd. & Boraginaceae & Tohum & 12.8 & 27.9 & & 79 \\
\hline Symphytum asperum Lepech. & Boraginaceae & Tohum & 1.2 & 36.9 & & 79 \\
\hline Symphytum officinale L. & Boraginaceae & Tohum & 0.6 & 39.6 & & 79 \\
\hline Symphytum orientale L. & Boraginaceae & Tohum & 0.9 & 38.5 & & 79 \\
\hline $\begin{array}{l}\text { Symphytum tuberosum L. ssp. } \\
\text { nodosum Schur. }\end{array}$ & Boraginaceae & Tohum & 10.6 & 27.5 & & 79 \\
\hline Trachystemon orientalis L. & Boraginaceae & Tohum & 3.8 & 29.3 & & 79 \\
\hline
\end{tabular}




\begin{tabular}{|c|c|c|c|c|c|c|}
\hline Bitki & Familya & $\begin{array}{l}\text { Çalıșılan } \\
\text { Kısım }\end{array}$ & $\begin{array}{c}\omega-3 \\
(\mathrm{ALA}) \\
(\%)\end{array}$ & $\begin{array}{c}\omega-6 \\
(\mathrm{LA}) \\
(\%)\end{array}$ & $\begin{array}{c}\omega-9 \\
(\mathrm{OA}) \\
(\%)\end{array}$ & Kaynak No. \\
\hline Juglans regia $\mathrm{L}$. & Juglandaceae & Tohum & 10 & 71 & 10 & 78 \\
\hline Salvia fruticosa Mill. & Lamiaceae & Tohum & & 60.73 & 24.01 & 80 \\
\hline Salvia tomentosa Mill. & Lamiaceae & Tohum & & 61.7 & 23.18 & 80 \\
\hline Stachys aleurites Boiss. \& Heldr. & Lamiaceae & Tohum & & 44.1 & 34.22 & 80 \\
\hline $\begin{array}{c}\text { Stachys cretica L. subsp. anatolica } \\
\text { Rech.f. }\end{array}$ & Lamiaceae & Tohum & 5.87 & 54.4 & 29.13 & 80 \\
\hline Olea europaea $\mathrm{L}$. & Oleaceae & Meyve & & 2.22 & $72-74$ & 78 \\
\hline Glaucium flavum Crantz. & Papaveraceae & Tohum & & 60.6 & 20.51 & 77 \\
\hline Papaver somniferum $\mathrm{L}$. & Papaveraceae & Tohum & 2.1 & 66 & 2 & 78 \\
\hline Sesamum indicum $\mathrm{L}$. & Pedaliaceae & Tohum & 2.5 & 58 & 17 & 78 \\
\hline Plantago scabra Moench. & Plantaginaceae & Tohum & & 28.1 & 40.7 & 77 \\
\hline Datura stramonium L. & Solanaceae & Tohum & & 53.5 & 25.5 & 79 \\
\hline
\end{tabular}

antienflamatuvar etkisi nedeniyle yararlı olduğunu göstermektedir. Ancak tüketim tarzında, yiyecek türünde veya formülasyon türünde birçok değişikliğin olması nedeniyle çalışmaların sonuçlarının güvenilir şekilde karşılaştırılması mümkün olamamaktadır [28]. DHA, beyin ve retinada bulunan fosfolipitlerdeki toplam yağ asitlerinin büyük bir kısmını oluşturmaktadır. Omega yağ asidi takviyesi ile kuru göz sendromu ve kontakt lens hassasiyetinin düzeltilmesi arasında ilişki olduğu bilinmektedir [44]. Birçok klinik çalışmada da omega-3 takviyesinin depresif semptomları azalttığına dair kanıtlar bulunmaktadır [50].

Omega-3 yağ asitlerinden $\alpha$-linolenik asite (ALA) kıyasla özellikle balık yağından elde edilen EPA ve DHA'nın kardiyovasküler hastalıklardan koruyucu etkisi daha yüksek bulunmuştur $[6,86]$. Dolayısıyla EPA ve DHA yönünden zengin balık tüketimi önem kazanmaktadır. Kardiyovasküler sistemin korunması için günlük 25-57 g omega-3 yönünden zengin balık tüketilmesi gerekmektedir [87]. Amerikan Kalp Derneği, haftada en az 2 porsiyon balık tüketimini önermektedir. Antiaterojenik ve antitrombotik etkinin görülmesinde omega-3'ler tarafindan LDL bağlanmasının düzenlenmesi, makrofaj seviyesi, proenflamatuvar mediyatörlerin oluşumundaki azalma, oksidatif stresin azaltılması gibi birçok mekanizmanın etkin olduğu saptanmıştır $[26,38,88]$.
Omega yağ asitlerinin tüm yararlı etkilerinin gözlenebilmesinde omega-6/omega-3 oranının önemli bir payı bulunmaktadır. Önerilen omega-6/omega-3 oranı 4:1 ya da daha düşüktür. Ancak batı diyetlerine bakıldığında bu oranın 10:1 ile 50:1 arasında olduğu görülmektedir [8]. Batı diyetindeki bu durumun oksidatif stresi arttırdığı, metabolik anomaliklere yol açtığı, davranışsal ve bilişsel bozuklukların ortaya çıkmasına neden olduğu, enflamasyonu ve kardiyovasküler hastalık riskini arttırdığı bilinmektedir $[30,36,89]$.

Amerikan Kalp Derneği'ne göre omega-3 dozu günlük 3 gramı geçmemeli ve omega-6 alım miktarı omega-3'ten; omega-9 alım miktarı da omega-6'dan daha az olmalıdır [5]. Trigliserit seviyesini düşürmek için daha yüksek dozlarda omega-3 alımı yapılacaksa mutlaka uzman hekim kontrolü sağlanmalıdır. Aksi durumda bu yağ asitlerinin yüksek dozları kanamaya ve bağışıklık sisteminin baskılanmasına yol açabilmektedir. Ayrıca kanama riski oluşturması nedeniyle omega-3 takviyelerinin antikoagülan ilaçlarla etkileşimine de dikkat edilmesi gerekmektedir. Günlük alım dozlarında ise ağızda hoş olmayan tat, mide rahatsızlığı, baş ağrısı ve diyare gibi yan etkiler gözlenebilmektedir [10].

Hamile ve emzirme dönemindeki kadınlarda ve bebeklerde omega-3 eksikliği görülmekte ve bu 
eksikliği aldıkları gıdalarla gidermeleri gerekmektedir. Hamile kadınların özellikle sinirsel gelişimin en belirgin olduğu hamileliğin üçüncü ayında yeterli miktarda omega-3 almaları gerekmektedir. Bebekler nispeten daha yüksek düzeylerde omega-3'e gereksinim duymaktadır. Gelişme öncesi bebekler omega-3 ihtiyacını anne sütünden ya da zenginleștirilmiş g1dalardan alabilmektedir. Hamilelikten itibaren yeni doğanlarda omega-3 takviyesinin hem retinada fotoreseptör gelişimine hem de bilişsel fonksiyonların gelişimine katkı sağladığı, psikiyatrik hastalıkları önlediği klinik çalışmalarla desteklenmektedir $[4,90]$. Hamilelerde, emziren annelerde ve çocuklarda balık tüketimine bağlı omega-3 alımında dikkat edilmesi gereken bir durum ise omega yönünden zengin olan yağlı balıkların (somon, uskumru vs.) başta cıva olmak üzere çevresel kirlilikleri taşıdıkları gerçeğidir. Doğrudan balık tüketimi ile omega-3 alımının sağlanması, özellikle okyanus balıklarındaki civa kontaminasyonu riski nedeniyle çocuklarda ve gebelik sırasında önerilmemektedir. İnsan vücudunda cıva artışının lipit peroksidasyonunu etkilemesi miyokard infarktüsü riski ile ilişkili bulunmuştur [91]. Çocuklarda nöropsikolojik değişikliklerin yaşanmasının da annelerin fazla miktarda balık tüketimi sonucu yüksek civa maruziyetleri ile ilişkili olduğu tespit edilmiştir [6].

Omega-6 yönünden zengin bitkiler arasında en başta. Helianthus annuus L. ( \%60-90, ayçiçeği), Carthamus tinctorius L. (\%78, kanola) ve O. biennis L. (\%76) gelmektedir (Tablo 3,4). Omega-6 yağ asidini piyasada temsil eden "evening primrose oil" adiyla anılan $O$. biennis L. bitkisinin yağ 1 , linoleik asit ve asıl olarak linoleik asidin metaboliti olan gama linoleik asit içermektedir. Santral sinir sistemi hastalığ olan multiple skleroz hastaları üzerinde yapılan çalışmada bir gruba plasebo diğerine evening primrose oil verilmiştir. Evening primrose oil verilen hastalarda bilişsel fonksiyonlarda artış ve ağrılarda azalma gözlenmiştir [92]. Yemeklerde kullanılan $H$. annuus L. en yaygın asitlerden olan linoleik ve oleik asitleri içermektedir. Linoleik asit yönünden zengin olması nedeniyle cildi besler. Yüksek oleik asit içeriği ise kardiyovasküler hastalıklara karşı koruyuculuğu ve kolesterol seviyesinin korunmasına destek sağlamaktadır [93].

Omega-9 yağ asidi olan oleik asidin Tablo 4 de görüldüğü gibi, en çok bulunduğu iki bitkisel kaynak ise Corylus avellana L. (find1k) (\%75-82) ve O. europaea L.(zeytin) (\%72-74) olarak sıralanmaktadır.
Yapılan çalışmalarda, damar tıkanıklığının azalmasıyla kardiyovasküler riskin de azalması fındık tüketimiyle ilişkilendirilmiştir [94]. Zeytinyağının yüksek oleik asit içeriği sayesinde KVS hastalıklarından koruyucu etkilerinin yanında, yemek sonrası insülin seviyelerinin düzenlenmesinde de etkili olduğu bilinmektedir [22].

Omega yağ asitleri balık ve bitkisel yağların tüketimi ile alınabildiği gibi, farmasötik preparatlarla da alınabilmektedir. Beslenmeyle alınacak omega yağ asitleri için pişirme tekniği önemlidir. Kızarmış balığa kıyasla haşlanmış balık tercih edilmektedir [91]. Omega-3 içerikli nanoformülasyonlar ile ilgili, son zamanlarda kardiyovasküler hastalıklar ve kanser üzerindeki etkisi yönünde birçok çalışma yapılmaktadir [95].

Günlük diyet, temel yağ asitlerini içeren yiyecekleri içermelidir. Bu gıdalardan bazılarının tüketimi; yüksek kalori değeri, alerji ve yüksek kolesterol içeriği gibi endişeler nedeniyle kullanımı kısıtlanabileceğinden, yeni esansiyel yağ asitleri kaynakları üzerine araştırmalar artmıştır. Son yıllarda beslenmede önemli bir role sahip olan yenilebilir mantarların, çeşitlilikleri, düşük kalori değeri, yüksek içerikli besin ve proteinler, kolesterol yokluğu ve her yerde bulunma gibi avantajlarla yağ asitlerinin alımına katkıda bulunabileceği düşünülmektedir. Mantarlarda bulunan lipit miktarı düşük olmasına rağmen, lipit içeriğinin önemli bir kısmını çoğu durumda yüksek linoleik, oleik ve linolenik asit içerikleri ile esansiyel yağ asitlerinin oluşturduğu bilinmektedir. Yapılan çalışmalarda çoğunlukla omega-6 ve omega-9 yağ asitlerine rastlanmaktadır. [96].

EPA ve DHA'nın çoğu, sucul ortamlardan yakalanan balıklardan elde edilerek insanların tüketimine sunulmuş olmakla birlikte son araştırmalar sürdürülebilir kaynaklara odaklanmıştır. Bu kaynaklar arasında su ürünleri yetiştiriciliği, krill, deniz mikroalgleri ve mikroalg benzeri protistler bulunmaktadır. Son yıllarda EPA ve DHA'ya artan talebi karşılamak için, bitki ve mikroalgler gibi farklı sürdürülebilir kaynakların üretimi ile küresel balık stoklarını geri kazanmak için balık yemlerinde karasal kökenli kaynakların birlikte kullanımının önemi de araştırmacılar tarafindan vurgulanmaktadır [97].

Sonuç olarak, omega yağ asitleri, çeşitli doğal kaynaklarda bulunmaları ve birçok biyolojik aktiviteye sahip olmaları nedeniyle beslenmede, gida takviyelerinde ve ilaçlarda değerli bileşenler olarak dikat 
çekmektedir. Birçok hastalık üzerinde yararlı etkiye sahip olmalarının antienflamatuvar ve antioksidan etkileri ile ilişkili olduğu görülmektedir. Omega yă̆ asitlerinin in vitro, in vivo ve klinik çalışmalarla desteklenen biyolojik etkilerine ait verilere rağmen son yıllarda etki bulunmayan çalışmaları nedeniyle de hala tartışmalı olan aktiviteleri ve bunların mekanizmalarının aydınlatılmasına yönelik ileri çalışmaların yapılması gerekmektedir.

\section{Kaynaklar}

1. Hossain S, Hashimoto M, Choudhury EK, Alam N, Hussain S, Hasan M, Mahmud I: Dietary mushroom (Pleurotus ostreatus) ameliorates atherogenic lipid in hypercholesterolaemic rats. Clinical and Experimental Pharmacology and Physiology 2003, 30(7): 470-475.

2. Parikh P, McDaniel MC, Ashen D, Miller JI, Sorrentino M, Chan V, Sperling LS: Diets and cardiovascular disease: An evidence-based assessment. Journal of the American College of Cardiology 2005, 45(9): 1379-1387.

3. Aydın A: Sağlı̆̆ımız ve omega-3 yağ asitleri. Sağlıkta ve Hastalıkta Beslenme Sempozyumu Dizisi, İstanbul, Türkiye, 2004; 81-189.

4. Uauy R, Hoffman D. R, Peirano P, Birch DG, Birch EE: Essential fatty acids in visual and brain development, Lipids 2001, 36(9): 885-895.

5. Elbossaty WF: Clinical influence of triple omega fatty acids (omega-3, 6, 9). Biomedical Journal of Scientific\&Technical Research 2018, 6(4): 5-6.

6. DeFilippis AP, Blaha MJ, Jacobson TA: Omega-3 fatty acids for cardiovascular disease prevention. Current Treatment Options in Cardiovascular Medicine 2010, 12(4): 365-380.

7. Patterson E, Wall R, Fitzgerald GF, Ross RP, Stanton C: Health implications of high dietary omega- 6 polyunsaturated fatty acids. Journal of Nutrition and Metabolism, 2012

8. Robertson R. Omega-3-6-9 Fatty Acids: A complete overview.; 2018, https://www.healthline.com/nutrition/omega-3-69-overview [Accessed: 21 February 2021]

9. Punia S, Sandhu KS, Siroha AK, Dhull SB: Omega 3-metabolism, absorption, bioavailability and health benefits $-\mathrm{A}$ review. Pharma Nutrition. 2019.100162.

10. NIH, National Institutes of Health Office of Dietary Supplements, Omega-3 fatty acids, (2019, April 25). Available from: https://ods.od.nih.gov/factsheets/Omega3FattyAcids-HealthProfessional/ (Accesed: 29 May 2020).

11. Konukoğlu D: Omega-3 ve omega-6 yağ asitlerinin özellikleri, etkileri ve kardiyovasküler hastalıklar ile ilişkiler. Türkiye
Aile Hekimliği Dergisi 2008, 12(3): 121-129.

12. Karabulut HA, Yandı İ: Su ürünlerindeki omega-3 yağ asitlerinin önemi ve sağlık üzerine etkisi. Su Ürünleri Dergisi 2006, 23(3): 339-342.

13. Rustan, AC, Drevon, CA,Fatty Acids: Structures and Properties. In Encyclopedia of Life Sciences. John Wiley \& Sons Ltd, 2005.

14. Çakmakçı S, Tahmas-Kahyaoğlu D: Yağ asitlerinin sağlık ve beslenme üzerine etkilerine genel bir bakış. Academic Food Journal/Akademik Gida 2012, 10(1): 103-113.

15. Yeşil E, Çelik A: Yağ asitleri ve antioksidanlar. Türkiye Klinikleri Kardiyoloji-Özel Konular 2017, 10(4): 274-280.

16. Simopoulos AP: The importance of the omega-6/omega-3 fatty acid ratio in cardiovascular disease and other chronic diseases. Experimental Biology and Medicine 2008, 233(6): 674-688.

17. Silva APDS, Da Costa WA, Salazar MDLAR., do Nascimento Bezerra P, Pires FCS, Ferreira MCR, Menezes EGO, Urbina GRO, de Carvalho RN: Commercial and therapeutic potential of plant-based fatty acids. Biochemistry and Health Benefits of Fatty Acids. IntechOpen, 2018. (Accesed: 24 February 2021)

18. Grossmann ME, Mizuno NK, Schuster T, Cleary MP: Punicic acid is an $\omega-5$ fatty acid capable of inhibiting breast cancer proliferation. International Journal of Oncology 2010, 36(2): 421-426.

19. García VL:The Omega 7 as a health strategy for the skin and mucous membranes. EC Nutrition 2019, 14(6): 484-489.

20. Aruna P, Venkataramanamma D, Singh AK, Singh RP: Health benefits of punicic acid: a review. Comprehensive Reviews in Food Science and Food Safety 2016, 15(1): 16-27.

21. Herbst MC: Fact sheet on palmitoleic acid (omega-7) Cancer Association of South Africa (CANSA), 2015, 1-8.

22. Lopez S, Bermudez B, Pacheco YM, Ortega A, Varela LM, Abia R, Muriana FJ. Oleic acid: the main component of olive oil on postprandial metabolic processes. In Preedy VR and Watson RR (eds), Olives and Olive Oil in Health and Disease Prevention, 2010: pp. 1385-1393.

23. Eseceli H, Değirmencioğlu A, Kahraman R: Omega yağ asitlerinin insan sağlığı yönünden önemi. Türkiye 9. Gıda Kongresi, 2006, 403-406

24. Göre M, Hacıkamiloğlu MS, Kurt O, The effects of omega fatty acids on human health. VII International Scientific Agriculture Symposium," Agrosym 2016"; October 6-9, 2016; Jahorina-Bosnia and Herzegovina.

25. Márquez-Fernández ME, Camargo $M$ : Therapeutic potential of omega fatty acids in breast cancer. Vitae 2019, 26(1): 23-43. 
26. Chang CL, Deckelbaum RJ: Omega-3 fatty acids: mechanisms underlying "protective effects" in atherosclerosis. Current Opinion in Lipidology 2013, 24(4): 345.

27. Simopoulos AP: An increase in the omega-6/omega-3 fatty acid ratio increases the risk for obesity. Nutrients 2016, 8(3): 128.

28. Marton LT, Goulart RDA, Carvalho, ACAD, Barbalho SM: Omega fatty acids and inflammatory bowel diseases: an overview. International Journal of Molecular Sciences 2019, 20(19): 4851.

29. Simopoulos AP: Omega-3 fatty acids and antioxidants in edible wild plants. Biological Research 2004, 37(2): 263-277.

30. Farooqui AA, Farooqui T: Prevention of oxidative stress by omega-3 fatty acids in the brain. In Hegde MV, Zanwar AA, Adekar SP (eds), Omega-3 Fatty Acids, Springer, Switzerland, 2016: pp. 239-249.

31. Wiest EF, Walsh-Wilcox MT, Walker MK: Omega-3 polyunsaturated fatty acids protect against cigarette smoke-induced oxidative stress and vascular dysfunction. Toxicological Sciences 2017, 156(1): 300-310.

32. Zanetti M, Gortan Cappellari G, Barbetta D, Semolic A, Barazzoni R: Omega 3 polyunsaturated fatty acids improve endothelial dysfunction in chronic renal failure: role of eNOS activation and of oxidative stress. Nutrients 2017, 9(8): 895 .

33. Kajarabille N, Hurtado JA, Peña-Quintana L, Peña M, Ruiz J, Diaz-Castro J, Rodríguez-Santana Y, Martin-Alvarez E, López-Frias M, Soldado O, Lara-Villoslada F, Ochoa JJ: Omega-3 LCPUFA supplement: a nutritional strategy to prevent maternal and neonatal oxidative stress. Maternal \& Child Nutrition 2017, 13(2): e12300.

34. Babchia N, Araujo AD, Leclère L, Buteau B, Martine L: Docosahexaenoic acid modulates oxidative stress over PI3K signaling pathway activation in age related macular degeneration. Journal of Cell Signaling 2017, 2(1) 1000137.

35. Bourre JM: Brain lipids and ageing. In: Raats M, De Groot $\mathrm{L}$ and Van Staveren W (eds), Food for the Ageing Population, NY: CRC Press; New York, USA. 2009: pp 219-251.

36. De Caterina R: $\mathrm{n}-3$ Fatty acids in cardiovascular disease. New England Journal of Medicine 2011, 364(25): 2439-2450.

37. Gogus U, Smith C: n-3 Omega fatty acids: a review of current knowledge. International Journal of Food Science \& Technology 2010, 45(3): 417-436.

38. Endo J, Arita M: Cardioprotective mechanism of omega-3 polyunsaturated fatty acids. Journal of Cardiology 2016, 67(1): 22-27.

39. Tur JA, Bibiloni MM, Sureda A, Pons A:Dietary sources of omega 3 fatty acids: public health risks and benefits. British Journal of Nutrition 2012, 107(S2): 23-52.
40. Schunck WH, Konkel A, Fischer R, Weylandt KH: Therapeutic potential of omega-3 fatty acid-derived epoxyeicosanoids in cardiovascular and inflammatory diseases, Pharmacology \& Therapeutics 2018, 183: 177-204.

41. Baker EJ, Miles EA, Burdge GC, Yaqoob P, Calder PC: Metabolism and functional effects of plant-derived omega-3 fatty acids in humans. Progress in Lipid Research 2016, 64: 30-56.

42. Behl, T., Grover, M., Shah, K., Makkar, R., Kaur, L., Sharma, S., Gupta, J: Role of omega-3-fatty acids in the management of diabetes and associated complications. In: Watson $\mathrm{R}$ and Preedy V (eds), Bioactive Food as Dietary Interventions for Diabetes. Academic Press; 2019: pp. 185-192.

43. Lalia AZ, Lanza IR: Insulin-sensitizing effects of omega-3 fatty acids: lost in translation?. Nutrients 2016, 8(6): 329.

44. Erdinest N, Shmueli O, Grossman Y, Ovadia H, Solomon A: Anti-inflammatory effects of alpha linolenic acid on human corneal epithelial cells. Investigative Ophthalmology \& Visual science 2012, 53(8): 4396-4406.

45. SanGiovanni JP, Chew EY: The role of omega-3 long-chain polyunsaturated fatty acids in health and disease of the retina. Progress in Retinal and Eye Research 2005, 24(1): 87-138.

46. Coletta, J. M., Bell, S. J., Roman, A. S: Omega-3 fatty acids and pregnancy. Reviews in Obstetrics and Gynecology 2010, 3(4): 163-171.

47. Georgakopoulos CD, Makri OE, Pagoulatos D, Vasilakis P, Peristeropoulou P, Kouli V, Eliopoulou MI, Psachoulia, C: Effect of omega-3 fatty acids dietary supplementation on ocular surface and tear film in diabetic patients with dry eye. Journal of the American College of Nutrition 2017, 36(1): 38-43.

48. Savitha P, Kumar SS: Effect of omega-3 fatty acids on memory-review. Research Journal of Pharmacy and Technology 2014, 7(6): 715-718.

49. Yehuda S: Omega-6/omega-3 ratio and brain-related functions. World Review of Nutrition and Dietetics 2013, 92: 37-56.

50. Grosso G, Galvano F, Marventano S, Malaguarnera M, Bucolo C, Drago F, Caraci F: Omega-3 fatty acids and depression: scientific evidence and biological mechanisms. Oxidative Medicine and Cellular Longevity 2014, 1-16.

51. Mazza M, Marano G, Traversi G, Mazza S, Janiri L: Neurobiological meaning of omega-3 fatty acids and their potential role in the treatment of schizophrenia. In Ronald Ross Watson \& Victor R. Preedy (Eds.), Omega Fatty Acids in Brain and Neurological Health,San Diego, Academic Press., 2019: pp. 275-294.

52. Dhingra S, Parle M: Herbal remedies and nutritional supplements in the treatment of depression: a review. Klinik Psikofarmakoloji Bülteni-Bulletin of Clinical Psychopharmacology 2012, 22(3): 286-292. 
53. Freeman MP: Omega-3 fatty acids in psychiatry: a review. Annals of Clinical Psychiatry 2000, 12(3): 159-165.

54. Das UN: Essential fatty acids-a review. Current Pharmaceutical Biotechnology, 2006, 7(6): 467-482.

55. D'Eliseo D, Velotti F: Omega-3 fatty acids and cancer cell cytotoxicity: implications for multi-targeted cancer therapy. Journal of Clinical Medicine 2016, 5(2): 15.

56. Black HS, Rhodes LE: Potential benefits of omega-3 fatty acids in non-melanoma skin cancer. Journal of Clinical Medicine $2016,5(2): 23$.

57. Ghanbarzadeh HD, Mohaddes M: The effect of omega fatty acids on Bcl-2 gene expression and protein production in cancerous gastric tissue. Multidisciplinary Cancer Investigation 2017, 1(4): 24-28.

58. Mortaz E, Moloudizargari M, Khosravi A, Asghari MH, Movassaghi M, Varahram M, Vaezi M, Redegeld. FA, Garssen J: EPA and DHA have selective toxicity for PBMCs from multiple myeloma patients in a partly caspase-dependent manner. Clinical Nutrition 2020, 39(7): 2137-2143.

59. Volpato M, Hull MA, Omega-3 polyunsaturated fatty acids as adjuvant therapy of colorectal cancer. Cancer and Metastasis Reviews 2018, 37(2-3): 545-555.

60. Villa-Vásquez SS, Márquez-Fernández ME, Camargo-Guerrero $\mathrm{M}$ : Cytotoxic and genotoxic activity of omega fatty acids in prostate Cancer Cells PC-3. Iatreia 2018, 31(4): 351-361.

61. Eswaramkunnath J, Kuriakose A, Abraham L: Omega fatty acids in prostate cancer-A review. Indian Journal of Pharmacy Practice 2018, 11(2): 65.

62. Hopkins MM, Meier KE: Omega-3 fatty acids and their impact on prostate cancer risk. Current Nutrition Reports 2016 , 5(1): 34-40.

63. Piombo G, Barouh N, Barea B, Boulanger R, Brat P, Pina M, Villeneuve P: Characterization of the seed oils from kiwi (Actinidia chinensis), passion fruit (Passiflora edulis) and guava (Psidium guajava). Oléagineux, Corps Gras, Lipides 2006, 13(2-3): 195-199.

64. Nengroo ZR, Rauf A: Fatty acid composition and antioxidant activities of five medicinal plants from Kashmir. Industrial Crops and Products 2019, 140: 111596.

65. Palić R, Stojanović G, Ranđelović N, Ranđelović V, Veličković $\mathrm{J}$ : The fatty acids from plants of the genus Achillea. Facta Universitatis-series: Physics, Chemistry and Technology 2000, 2(2): 101-104.

66. Mihaela P, Josef R, Monica N, Rudolf Z: Perspectives of safflower oil as biodiesel source for South Eastern Europe (comparative study: Safflower, soybean and rapeseed). Fuel 2013 , 111: 114-119.
67. Callaway JC: Hempseed as a nutritional resource: An overview. Euphytica 2004, 140(1-2): 65-72.

68. Sharafi Y, Majidi MM, Goli SAH., Rashidi F: Oil content and fatty acids composition in Brassica species. International Journal of Food Properties 2015, 18(10): 2145-2154.

69. Woodfield HK, Harwood JL: Oilseed Crops: Linseed, Rapeseed, Soybean, and Sunflower. In Brian T, Brian GM, Denis JM (eds), Encyclopedia of Applied Plant Sciences. Academic Press; Amsterdam, Netherlands. 2017: Vol 3. pp. 34-38.

70. Imbrea F, Jurcoane S, Halmajan HV, Duda M, Botos L: Camelina sativa: A new source of vegetal oils. Romanian Biotechnological Letters 2011, 16(3): 6263-6270.

71. Chi X, Yang Q, Pan L, Chen M, He Y, Yang Z, Yu S: Isolation and characterization of fatty acid desaturase genes from peanut (Arachis hypogaea L.). Plant Cell Reports 2011, 30(8): 1393-1404.

72. Joshi A, Sharma A, Pandey DP, Bachheti RK: Physico-chemical properties of Perilla frutescens seeds. Der Pharma Chemica $2015,7(5): 35-41$.

73. Mohd Ali N, Yeap SK, Ho WY, Beh BK, Tan SW, Tan SG: The promising future of chia, Salvia hispanica L. Journal of Biomedicine and Biotechnology 2012, 2012: 171956.

74. Siriamornpun S, Suttajit M: Microchemical components and antioxidant activity of different morphological parts of Thai wild purslane (Portulaca oleracea). Weed Science 2010, 58(3): 182-188.

75. Parry J, Yu L: Fatty acid content and antioxidant properties of cold-pressed black raspberry seed oil and meal. Journal of Food Science 2004, 69(3): 189-193.

76. Lutterodt H, Slavin M, Whent M, Turner E,Yu LL: Fatty acid composition, oxidative stability, antioxidant and antiproliferative properties of selected cold-pressed grape seed oils and flours. Food Chemistry 2011, 128(2): 391-399.

77. Ozcan T: Fatty acid composition of seed oils in some sand dune vegetation species from Turkey. Chemistry of Natural Compounds 2014, 50(5): 804-809.

78. Kolayli S, Tarhan O, Kara M, Aliyazicioglu R, Kucuk M: An investigation of frequently consumed edible oils in Turkey in terms of omega fatty acids. Chemistry of Natural Compounds 2011, 47(3): 347.

79. Özcan T: Analysis of the total oil and fatty acid composition of seeds of some Boraginaceae taxa from Turkey. Plant Systematics and Evolution 2008, 274(3-4): 143-153.

80. Özkan G, Göktürk RS, Kıralan M, Hassanien MFR: Fatty acids and tocopherols of Turkish Salvia fruticosa, Salvia tomentosa, Stachys aleurites and Stachys cretica subsp. anatolica seed oils. Rivista Italiana Delle Sostanze Grasse 2018, 95(1): 17-21. 
81. Karaca E, Aytaç S: Yağ bitkilerinde yağ asitleri kompozisyonu üzerine etki eden faktörler. Anadolu Tarım Bilimleri Dergisi 2007, 22(1):123-131.

82. Onneken P: Salvia hispanica L (Chia Seeds) as brain superfood-how seeds increase-How seeds increase intelligence, Global Journal of Health Science 2018, 10(7): 1-69.

83. Muñoz LA, Cobos A, Diaz O, Aguilera JM: Chia seed (Salvia hispanica): an ancient grain and a new functional food. Food Reviews International 2013, 29(4): 394-408.

84. Rashid N, Dar PA, Ahmad HN, Rather SA: Alsi (Linum usitatissimum (Linn.): A potential multifaceted Unani drug. Journal of Pharmacognosy and Phytochemistry 2018, 7(5): 3294-3300.

85. Arslanoğlu F, Aytac S: The important in terms of health of flax (Linum usitatissimum L.). International Journal of Life Sciences and Biotechnology 2020, 3(1): 95-107.

86. Jung UJ, Torrejon C, Tighe AP, Deckelbaum RJ: n- 3 Fatty acids and cardiovascular disease: mechanisms underlying beneficial effects. The American Journal of Clinical Nutrition 2008, 87(6): 2003S-2009S.

87. Psota TL, Gebauer SK, Kris-Etherton P: Dietary omega-3 fatty acid intake and cardiovascular risk. The American Journal of Cardiology 2006, 98(4): 3-18.

88. Gajos G: Omega-3 polyunsaturated fatty acids: is their future vİtalized or reduced? Cardiovascular Research 2019, 115(6): e58-e60.

89. Johnson M, Bradford C: Omega-3, omega-6 and omega-9 fatty acids: implications for cardiovascular and other diseases. Journal of Glycomics and Lipidomics 2014, 4: 123.

90. Nishi D, Su KP, Usuda K, Chang JPC, Hamazaki K, Ishima T, Sanoh Y, Itoa H, Isakaa K, Tachibanai Y, Tanigakij S, Suzukij T, Hashimotog K, Matsuoka YJ: Plasma estradiol levels and antidepressant effects of omega-3 fatty acids in pregnant women. Brain, Behavior and Immunity 2020, 85: 29-34.

91. Roy J, Le Guennec JY: Cardioprotective effects of omega 3 fatty acids: origin of the variability. Journal of Muscle Research and Cell Motility 2017,38(1): 25-30.

92. Majdinasab N, Namjoyan F, Taghizadeh M, Saki H: The effect of evening primrose oil on fatigue and quality of life in patients with multiple sclerosis. Neuropsychiatric Disease and Treatment 2018, 14: 1505-1512.

93. Pal D, Sunflower (Helianthus annuus L.) Seeds in health and nutrition. In Victor RP, Ronald RW, Vinood BP (eds), Nuts and Seeds in Health and Disease Prevention. Academic Press; San Diego, CA, USA. 2011: pp. 1097-1105

94. Mollica A, Zengin G, Stefanucci A, Ferrante C, Menghini L, Orlando G, Wakeel OK: Nutraceutical potential of Corylus avellana daily supplements for obesity and related dysmetabolism. Journal of Functional Foods 2018, 47: 562-574.
95. Serini S, Cassano R, Trombino S Calviello G: Nanomedicine-based formulations containing $\omega-3$ polyunsaturated fatty acids: Potential application in cardiovascular and neoplastic diseases. International Journal of Nanomedicine 2019, 14: 2809-2828.

96. Sande D, de Oliveira GP, Moura MAF, de Almeida Martins B, Lima MTNS, Takahashi JA: Edible mushrooms as a ubiquitous source of essential fatty acids. Food Research International 2019, 108524.

97. Bağcı E, Can E: Omega-3 yağ asitleri temininde sürdürülebilir kaynakların rolü. Tunceli Üniversitesi Bilim ve Gençlik Dergisi 2015, 3: 77-89. 